\title{
Wireless Technologies For Marketing And Management Professionals
}

Gary R. Schornack, (E-mail: gary.schornack@cudenver.edu), University of Colorado, Denver Charles E. Beck, (E-mail: cbeck@carbon.cudenver.edu), University of Colorado, Colorado Springs

\begin{abstract}
Wireless technology is rapidly expanding market in business. A survey of literature and executives in Colorado indicates extensive use of cell phones predominating in all businesses. Secondary wireless technology (wireless mouse, LAN, keyboards, PDA) is gradually expanding. The future holds additional expansion in Hot Spots for use away form the homeloffice environment. Major concerns with wireless technology involve both security and standardization, which will determine expanded use in the future.
\end{abstract}

\section{Problem}

Electronic commerce is going to be fundamentally changed by the fact that wireless access is moving beyond computer users into the mainstream (Rash, 2000).

Wireless technology has become an expanding phenomena in today's business environment. As with any new technology, however, questions arise concerning the applications of wireless technology in meeting business objectives. The fact that a business has the opportunity to use wireless does not in itself mean that such technology helps the business.

To address this concern, our study examines the current state of usage of wireless technology through a literature review, and the results of interviews with business executives in the Denver Rocky Mountain Region.

\section{Market Growth}

Wireless communication has become a significant growth area in recent years. According to one projection, 1.1 billion users of wireless devices include some 90 million that are Internet-ready; and half of the Internet traffic will be wireless (Hulme, 2001). On the popular level, Computerworld characterizes the phenomenon as a "feeding frenzy going on in wireless" (2000). This awareness of the wireless market involves more than hype. According to Preimesberger, "consumers have shown themselves willing to spend more than ever before on media and communications hardware and services" (2003).

Recent market projections identified a likely scenario for 2003:

- wireless penetration levels in excess of $40 \%$

- growth rate in Internet connections of $80 \%$

- 600 million Internet-enables wireless phones

- $\quad$ wireless lines globally exceeding wirelines

- $\quad$ by 2005 , more Internet access through a wireless device rather than through a PC.

[Menezes, 2000] 
Figure 1 portrays the relative growth of wireless from 1990 and projected through 2006.

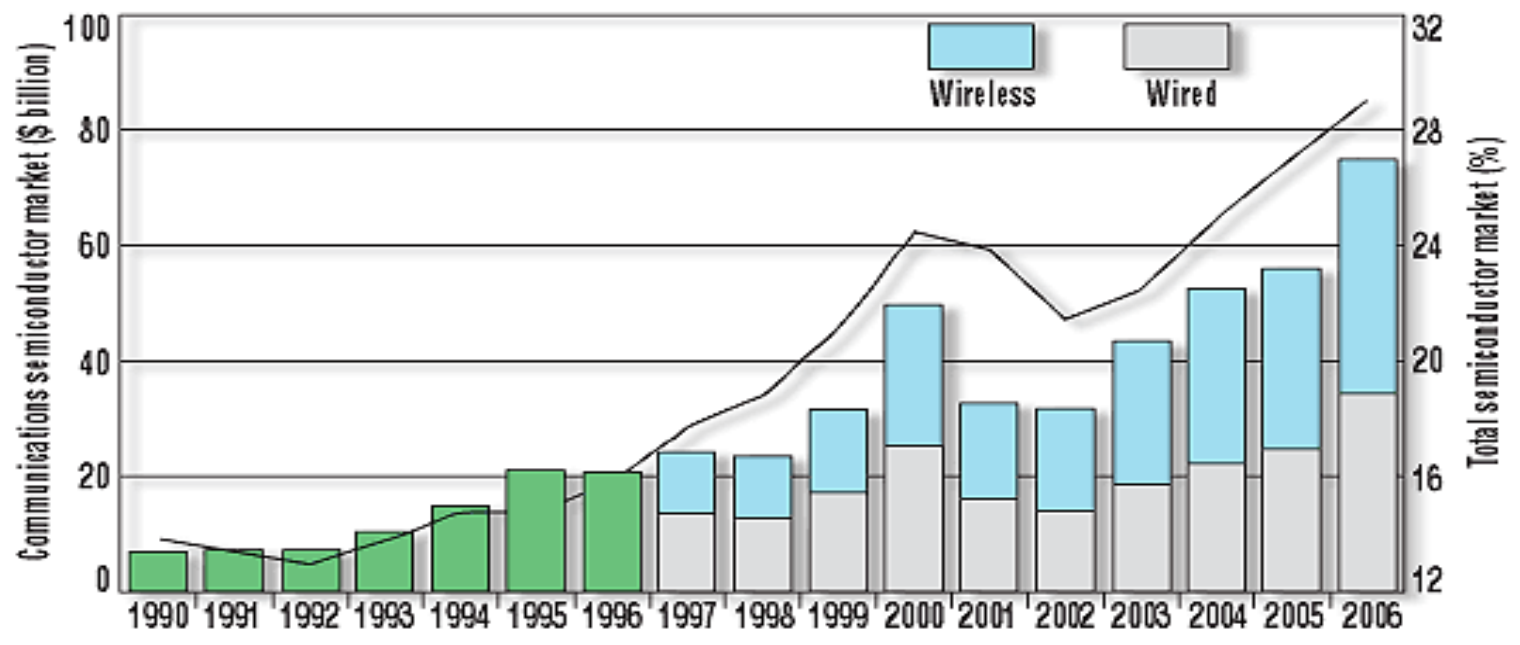

[Frenzel, 2002]

Wireless technology now accounts for half of all communications semiconductors sold. As these market projections by Motorola's Semiconductor Products Sector show, the communications sector of total chip sales will enjoy steady growth (courtesy of World Semiconductor Trade Statistics, SPS, Dataquest).

\section{Figure 1: Wired and Wireless Growth}

Overall market growth in wireless actually consists of two distinct aspects, phone lines and other wireless devices.

Wireless Phones. Most of the focus in the wireless discussion involves the cellular phone, "one piece of the wireless connection revolution" (Frenzel, 2002). Such connectivity helps any person in an emergency, but it especially permits businesses to maintain contact regardless of location. Growth within wireless phone service means that "wireless has phenomenal growth ahead, especially for substitution of wireline service" (Luna, 2002). The fact that the Federal Government has mandated the portability of a customer's phone number, regardless of wireless service provider, attests to the impact of this wireless-line substitution. The FCC number portability ruling will reshape the wireless industry in the following ways:

- Wireline carries must port numbers to wireless providers whose coverage area overlaps with the geographic area of the number.

- Wireline carriers operating in the 100 largest metropolitan Statistical Areas must support wireline-towireless number porting by November 24, 2003 unless they can demonstrate that compliance would be technically infeasible.

- Gartner reaffirms its earlier predictors that the FCC's actions will change the telecom marketplace. Carries will need to adjust their business plans and services offerings accordingly. [Gartner Inc, November 11, 2003]

Overall, Wireless lines will exceed wireless (Menezes, 2000). Worldwide, the rebuilding in Iraq used wireless networks as the basis, since its cost of infrastructure is much simpler than traditional land lines (The Wireless Week, December 17, 2003). Phone lines are part of the wireless revolution. Phones permit an alternate means of accessing the Internet, e-mail, and instant messaging. In fact, "In only one decade, e-mail has gone from a tiny niche to the primary way that we communicate in business" (Frenzel, 2002). 


\section{Other Wireless Technology}

The wireless movement includes more than just phones. It also includes ways to communicate between various types of electronic equipment. Wireless identifies some of these alternatives:

- wireless PC and peripheral connections

- $\quad$ wireless headsets

- $\quad$ wireless local-area network (LAN) connections

[Sep 30, 2002]

Such connectivity has become a necessity as "we share our PC resources, connect our entertainment equipment, and monitor and control our home functions-with no wires at all" (Sep 30, 2002). Connectivity is not limited to a home or office location, but includes sites ranging from coffee shops to shopping malls and transportation terminals (Preimesberger, 2003). The latest phenomenon involves "hotspots" of "Wi-Fi" connections. According to Walker, about 20,000 Wi-Fi access points appear in "airports, train stations, hotels, coffee shops and other open places, and many charge for access by the minute, hour or day" (2003). Such a dynamic growth represents a shift in the wireless market, opening new alternatives for entrepreneurs and new concerns for a wide range of users.

\section{Wireless - Mobility Expansion}

The combination of information and technology is breaking down barriers. On the one hand, it applies to both the business world and the entertainment world (Businesss Wire, July 24, 2003). People can multi-task, not limited to one realm of experience only. For example, wireless technology opens the possibility "to communicate with my clients in a cost-effective way, perform projects successfully from beginning to end, stay in touch with my bookkeeper and administrative assistant, and do my banking" (Tudor, 2003). Ultimately for the information age, wireless technology expands potential by overcoming the limitation of physical place:

When you don't have to plug in anywhere, you are truly mobile. You can carry your computer from one place to another and still be connected to a network. Yes, that's great at home or at work. But it's even greater anywhere else you might carry a computer: airports, hotels, other people's offices, even a coffee shop or restaurant (Alsop, 2002).

The direction of mobility is clear for marketing and management professionals. The mobility aspect of the wireless revolution ultimately gives "business 'anywhere, anytime' access to information" (Nelson, 2000).

The wireless expansion builds on a combination of hardware and software development. Existing technology already can achieve much of the change, with wireless applications able to download both data and images at a transfer rate faster than most local area networks (Gilkes, 2001). Microsoft has even entered the wireless age, adapting its Windows operating platform to wireless applications (Fitchard, 2002). Wireless technology for business actually builds on the Global Positioning Satellite system, which enables the handling of massive amounts of data. "A hybrid hardware/software architecture involving multiple processors will be used as a platform for real-time wireless GPS applications with various functions, features and capabilities" (Gilkes, 2001). Use of global satellites, originally designed to help the military, thus provide the technological infrastructure to expand wireless technology for business uses.

\section{Wireless - The Next Level}

Wireless technology does nothing of itself; it requires leaders to expand and apply its potential. On the practical level, "from web services to wireless, business-technology leaders invest in the future" (Guzman, 2003). Overall research and development spending for wireless has expanded recently, as "companies are again willing to take a risk with promising new technologies - even at considerable investment" (Preimesberger, 2003). According to Bill Gates' keynote for the Microsoft mobility developer's conference, "We are going to invest, invest, and invest to make our mobility platform the most popular platform, which will be the fastest moving of all of our businesses" 
(Torode \& Lingblom, 2003). As a result of such investment, "wireless technology continues to revolutionize the way the world does business, and also how everyday people play and communicate" (Business Wire, July 24, 2003).

From the user's perspective, the next level of wireless brings a more complete integration of all information needs. Such integration includes appointments, banking, stock trades, travel reservations, and photo delivery (Alsop, 2002). For businesses, wireless permits communication through hand-held devices, fulfilling the promise of "one-to-one promise with the ability to target promotions, product data, customer alerts and even personalized pricing strategies right to an individual's hip pocket" (Nelson, 2000). Overall, using and expanding wireless capacities enables businesses to focus on improved customer relations (Business Wire, July 24, 2003). With all these applications, it is evident that there are no limitations for wireless technology applications.

\section{Methodology}

With the rapid development of wireless, existing research is sporadic and largely anecdotal. To determine the extent of wireless usage, we have combined an extensive review of literature since January 2000. Our research included 260 personal interviews with top-level business executives in the Denver metropolitan region. This research was conducted over the past 10 months. The study included 10 major categories of industries as classified by the Standard Industrial Classification system. The companies were analyzed based on size and industry classification. During the personal interviews, executives were questioned on the following six categories of wireless: Cell phone, Wireless Mouse, Wireless LAN, Wireless keyboard, PDA, and Other.

\section{Table 1: Descriptive Statistics of Company Interviews}

Total Number of interviewed companies

\section{Types of industries categorized by SIC codes}

1. Oil and Gas, Construction, Builders $\quad 15$

2. Food, Fabrics, Pharmaceutical, Cosmetic products 11

3. Glass, Metals, Hand tools, Computers, Appliances, Industrial tools 12

4. Transportation, Communications, Broadcasting 18

5. Wholesale, Retail 42

6. Financial institutions, Real estate 43

7. Automotive, Computer, Business, Personal Services $\quad 51$

8. Health Care, Legal, Professional Services 31

9. Public Administration $\quad 3$

10. Unknown $\quad 34$

\section{Size of Companies}

Less than 50 employees

Between 50-150 employees

Between 150-500 employees $\quad 31$

Between 500-1000 employees $\quad 13$

Between 1000-5000 employees $\quad 25$

More than 5000 employees $\quad 26$

\section{Results of Current Wireless Usage}

In current usage, most discussion of wireless technology focuses on cell phones, with the other areas not yet gaining much discussion in the literature. Our discussion here will begin with cell phones, and will include the combined findings of our survey on Denver executives. 


\section{Cell phone}

The use of cellular phones has expanded significantly in recent years. In fact, wireless would replace traditional phone lines if wireless networks offered a wider range of coverage areas (Rash, 2000). Even so, the use of traditional phone service has been shrinking as customers increasingly use the Internet for e-mails, on-line shopping, and entertainment (Munro, 2002). Cell phone customers were originally limited in using phones for Internet access because the phone companies lacked enabling software for such access (Rash, 2000). However, the cellular companies have adapted and now market multiple Internet-based services along with traditional phone service.

While cell usage has expanded overall, the 18-24 year group has some unique characteristics as cellular users (Arato, 2002):

- $\quad$ more likely to buy on impulse (41\% more likely than all cell buyers)

- $\quad$ more likely to buy in electronic specialty dealers

- $\quad$ spend more on a phone (average $\$ 68$ vs older buyers \$59) because they shop at these traditionally higherpriced outlets

- $\quad$ more likely to base purchase decisions on product appearance compared with older groups

- more likely to buy at regular price instead of on promotion.

The uniqueness of this age group may be very similar to marketing and management professionals, based on the distinctive characteristics of their business.

\section{Other Wireless Applications}

According to Kiplinger, the use of credit cards is expanding for mobile point of sale, such as pizza delivery, cab rental, car rental, and services (plumbers, nurseries). Compared to verbal exchange of credit information (more open to fraud), "clearinghouses give discounts to firms that swipe cards on a card processor, portable or otherwise" (The Kiplinger Letter, April 17, 2003).

A recent survey of 1,000 wireless developers by Evans Data clearly shows that the Multimedia Messaging Service (MMS), introduced only 22 months ago, is now by far the hottest new component being used in wireless application development. More than 25 percent of the developers surveyed said they have begun writing applications using MMS. That is a good number at this early stage (Preimesberger, 2003).

Sales and Marketing Management Magazine published the results of a survey questioning their subscriber on the following question:

Figure 2: How Tech Savvy are Your Salespeople?

Source: $S \& M M, 2003$

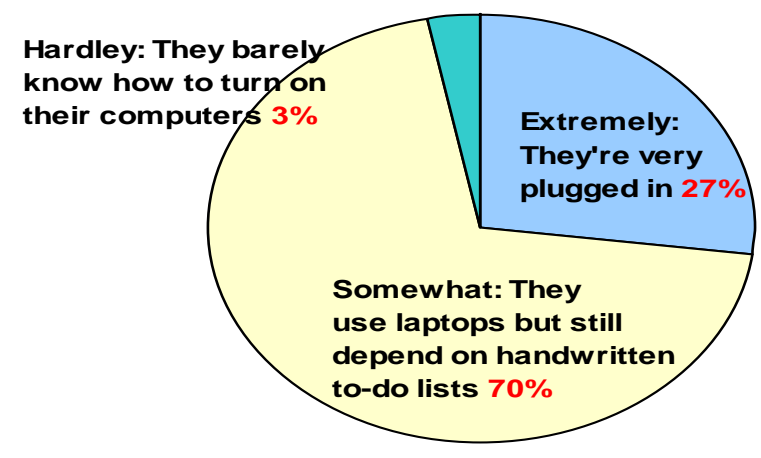


With the price of PDAs in general coming way down in the last year or so, more and more people and organizations are considering purchasing them (Preimesberger, 2003). PDA dynamic functionality combined with wireless capabilities will enhance salespeople's ability to communicate.

\section{Survey of Denver Executives}

Using the survey data, we have divided the results into small companies (less than 50 employees) and larger companies. Each executive was asked to identify the percentage of employees in their organization that use the following wireless devices. Table 2 shows the number of companies utilizing each wireless device at the given percentage level of use by its employees.

\begin{tabular}{|c|c|c|c|c|c|c|c|c|c|c|}
\hline \multirow[b]{2}{*}{$\begin{array}{l}\text { Percentage } \\
\text { level of use }\end{array}$} & \multicolumn{5}{|c|}{$\begin{array}{c}\text { Large Companies } \\
\text { (more than } 50 \text { employees) }\end{array}$} & \multicolumn{5}{|c|}{$\begin{array}{c}\text { Small Companies } \\
\text { (less than } 50 \text { employees) }\end{array}$} \\
\hline & $<25 \%$ & $25-49 \%$ & $50-74 \%$ & $75-99 \%$ & $100 \%$ & $<25 \%$ & $25-49 \%$ & $50-74 \%$ & $75-99 \%$ & $100 \%$ \\
\hline Cellphone & 13 & 7 & 23 & 54 & 42 & 9 & 7 & 9 & 25 & 63 \\
\hline Mouse & 44 & 11 & 2 & 5 & 2 & 24 & 7 & 6 & 0 & 60 \\
\hline LAN & 28 & 7 & 6 & 9 & 3 & 12 & 7 & 6 & 5 & 12 \\
\hline Keyboard & 40 & 8 & 2 & 4 & 2 & 20 & 5 & 5 & 0 & 6 \\
\hline PDA & 48 & 11 & 26 & 21 & 5 & 32 & 12 & 12 & 7 & 10 \\
\hline Other & 2 & 0 & 1 & 1 & 0 & 2 & 0 & 3 & 1 & 2 \\
\hline
\end{tabular}

\section{Current Status - Marketing Usability}

Wireless Technology provides the potential for every marketing and management professional to communicate everywhere and everyplace twenty-four hour a day. Wireless access to the Internet is expanding rapidly. According to The Kiplinger Letter, wireless access exists at airports, hotels and specialty shops such as Starbucks; it is expanding to gas stations such as Conoco and Circle K; and a "new AT\&T - Intel - IBM hot - spot venture will blanket 50 top markets" (Dec. 6, 2002). Communication News reports some significant finding among businesses with wireless usage (April, 2002):

- $\quad$ sales increases of $10 \%$ to $20 \%$

- $\quad$ reduced customer wait times of as much as $80 \%$

- $\quad$ increases in service calls up to $32 \%$

- $\quad$ service-call responsiveness improvements of $7 \%$

Although the longest payback period found was 30 months, most businesses achieved payback in just a few months (Gillott, 2002).

When Bill Gates speaks people listen: "People are very excited to get information wherever they are. I think wireless is the key component in what we're thinking about here in this multi-device era. Even though people have seen amazing things in the past, I think they're going to be really surprised. Much of that surprise will come from erasing the distinction between voice and data services. It's a world where voice and data have been separate, by bringing those together we're really going to surprise people with what they can do" (Communications Today, 2000). "Microsoft will spend a significant amount of research and development in this area" (Torode \& Lingblom, 2003). "The revolution is taking place right now: The years from 2000 to 2010 will be the digital decade" (Bill Gates, 2003). 
In addition to the "traditional" wireless access, the Wi-fi service providers are targeting business travelers as their main focus. Small businesses (typically cafes) are seeking to use Wi-Fi as a means of attracting new customers. Additionally, users themselves are setting up loose networks to "publicize where these free hot spots can be found, the codes you need to log on, and the rules for using them" (Hellweg, 2003).

\section{The Future is Now - Hot Spots}

One of the newest developments in wireless technology is wireless fidelity, commonly called "Wi-Fi" to create a "hot spot." At a "hot spot" location, a laptop user can gain access to a wireless, high-speed Internet link (The Consumers' Observation Post, August 2003). According to Munro, a Wi-Fi device (access point) consists of an electronics component with a transmitting antenna; the device uses a weak signal that uses part of the electromagnetic spectrum not requiring approval by the FCC. For Washington policy makers, the expansion of technology outside of current jurisdictions raises concerns in the oversight of telecommunications.

Individuals and small companies welcome the opportunity to deploy these devices, "whether they're in isolated rural communities, downtown coffee shops, or suburban housing developments" (5/11/2002). Our discussion includes the significance of hot spots for the Denver survey, and expected growth in this wireless technology.

\section{Hot Spots and the Denver Survey}

The issue of Wi-Fi devices does not appear in our survey of Denver survey both because of the newness of the technology and the fact that Denver was not at the forefront of this new area. Intel's survey found Portland, OR as the top "unwired city" with 130 hot-spot locations. Denver is the $8^{\text {th }}$ most "unwired city" in Intel's survey of 100 cities with the availability of hot spots (Beauprez, 2003). The survey ranked the following top cities based on the number of public and commercial wireless access points. See Table 3.

\section{Table 3: Rank of the Top Wireless Cities}

\begin{tabular}{|c|c|c|}
\hline 1. Portland, OR & 6. & Washington, DC \\
\hline 2. San Francisco, CA & 7. & San Diego, CA \\
\hline Austin, TX & 8. & Denver, CO \\
\hline Seattle, WA & 9. & Ventura, CA \\
\hline 5. Orange County, CA & 10. & Boston, MA \\
\hline
\end{tabular}

\section{Concerns}

Wireless expansion brings with it two major areas of concern, security and standardization. These are major issues that will determine growth and expansion of wireless applications in the future.

\section{Security}

Security becomes a major concern with wireless. For local area networks, un-authorized users could pick up signals, along with the authorized users. In addition, people using wireless mouse in close proximity may trigger a response on the wring computer. Connectivity initiatives bring a new phenomenon: "Wireless access is everywhere - and rarely well- secured" (Coffee, 2002).

Hot spots provide instant access for multiple users. However, "No public hot spot comes with built-in security" (Hellweg, 2003). Hot spots basically expand the concerns addressed but not answered since the turn of the century. As a result, "Security worries could trip up wireless e-commerce takeoff....If the wireless industry doesn't Implement end-to-end security and convince consumers of that, there will be no e-commerce business" (Bruno, 2000). 


\section{Standardization}

Part of the answer to the security concerns involves proper sets of standards. According to Laura Kahler at Hewlett Packard, businesses have a strong reason for supporting new standards: "The new standard is an important step forward in ensuring greater privacy and security in regards to wireless transactions" (Peckham, 2003). Creating security requires a unified delivery of date throughout the system, which is "complicated by different types of networks which deal with location and presence differently. The carriers traditionally have held onto this data and not exported it. They don't have a business model or a billing structure" (Infoworld, 2001). The cost of technology expands the potential: "Cheap wireless high-speed Internet hookups are on the horizon, thanks to a pact by the WiMAX group of equipment vendors...Intel, Nokia and others...to standardize wireless broadband equipment" (Kiplinger Letter, May 9, 2003). "There are many within the industry who would grant that most of the barriers constraining the wireless Internet's growth will be overcome once various issues of standardization are resolved". Industry leadership in wireless standards is key to ensuring growth and consumer satisfaction.

\section{Recommendations}

The EDC survey also reports that R\&D spending (and hiring) in the wireless development sector is up over the last 12 months. This is a good indicator overall for the industry. Why? Because it shows that companies are again willing to take a risk with promising new technologies - even at considerable investment (Preimesberger, 2003).

According to Bill Gates, "the key ingredient that can solve these problems is largely about software breaking down boundaries. That's why our goal is to achieve what we call "seamless computing" - between the structured and unstructured processes, between the devices, between the organizations" (Schlender, 2003).

It is clear that for the wireless industry to grow there must be a new level of confidence in the security of wireless devices. The level of customer confidence must also continue to improve in order to see growth in the wireless sector. It is apparent that with so many directions and intense competition, that an industry standard must emerge.

\section{Conclusion}

We've reached the point where the costs of communication between buyers and sellers matters less than the value of the goods being sold. Perhaps more important, we've reached the point at which you don't have to be a computer user to engage in electronic commerce (Infoworld, 2001). According to Bill Gates "the Wi Fi has today become [fantastic]. It is essential in order to remain [connected] when traveling or, at home, to allow the various electronic devices to communicate with each other, or even just to walk from one room to another with one's portable computer (Bill Gates, 2003).

What marketing professional just wants to live a boring working life delivering, mediocre, lukewarm average service to customers? The wireless world of electronics may not ever measure up to a customer's real-world experience. The customer is ever-changing. Each company needs to understand the implications of every wireless technology and what it means to the company in terms of developing the customer's relationship. The relationship with the customers is never-ending if it keeps on improving. No one should have to wait and rely on their competition for the new innovations.

\section{References}

1. $\quad$ Alsop, S. (2002). Awake from a wireless dream. Fortune, 144(7), 66.

2. Arato, P. (2002). 18-to 24-year-olds buy wireless at higher rate, higher prices: NPD. Twice, (December 23).

3. Barthold, J. (2002). Verizon trial breathes life into fixed wireless market. Telephony, (August 12), 14.

4. Beauprez, J. (2003). Denver rates no. 8 in survey of wireless net hotspots. Denver Post, (March 5). 
5. Beckman, K. (1999). Wireless e-commerce to drive online security. Radio Communications Report, 18(45), 44.

6. Bill Gates sets Geneva on fire and celebrates wireless Internet. Retrieved December 5, 2003 from http://www.geneva.ch/telecom03_wireless.htm.

7. Botelho, G. (2003). The next information age. CNN. Retrieved October 15, 2003, from http://www.cnn.com/2003/TECH/ptech/10/15/sprj.ws.overview/index.html.

8. Bruno, A. (2000). Security market turns its attention to wireless e-commerce. Radio Communications Report, 19(4), 8.

9. Bruno, A. (2000). Security worries could trip up wireless e-commerce. Radio Communications Report, 19(2), and 14.

10. Business Wire. (2003). Viva las wireless! (July 24).

11. Coffee, P. (2002). Technology trends in 2002. eWeek, (December 23/30), 41.

12. Communications Today. (2000). Gates: wireless data, voice all the same. (Feb 29).

13. The consumers' observation post. (2003). would you like wi-fi with that? Consumers' Research Magazine, 86(8), 40.

14. Fitchard, K. (2002). Nokia fears fuel Microsoft's wireless foray. Telephony, 242(39), 14.

15. Fitzgerald, M. (2003). Hand-Held: the new mobility. InformationWeek, (October 6), 88.

16. Frenzel, L. (2002). The lure of wireless is irresistible. Electronic Design, 50(20), 51.

17. Gareiss, R. (2003). Wireless access on a roll. InformationWeek, (April 7), 70.

18. Gerard, A. (1996). Mobile lifestyle drives wireless. Electronic Engineering Times, 908, 65.

19. Gilkes, A. (2001). Mobile devices: real-time GPS around the corner. Electronic Engineering Times, (January 9).

20. Gillott, I. (2002). The ROI benefits of wireless. Communications News, 39(4), 6.

21. Granelli, J. S. (2003). SBC will plug into wireless net market. Los Angeles Times, (August 6), 1.

22. Greenemeier, L. (2003). The PC factor. InformationWeek, (April 7), 37.

23. Guzman, D. (2003). Prepared to move forward. InformationWeek, (January 27), 44.

24. Hamblen, M. (2000). Packages hit wireless market. Computerworld, 34(10), 12.

25. Hellweg, E. (2003). Wireless A-Go-Go. PC World, (September 11).

26. Hulme, G. (2001). Certicom targets wireless market. InformationWeek, (January 22).

27. Infoworld. (2001). Wireless connection. (October 1), 38.

28. The Kiplinger Letter. (2002). vol. 79, no. 49 (December 6).

29. The Kiplinger Letter. (2003). vol. 80, no. 16 (April 17).

30. The Kiplinger Letter. (2003). vol. 80, no. 19 (May 9).

31. Luna, L. (2002). Laurel begins Sprint PCS reign looking for a little class. Telephony, 242(39), 14.

32. Menezes, J. (2000). Web brings 'immense power' to wireless world. Enterprise Computing, (April 28).

33. Molta, D. (2003). E-Mail without wires. Network Computing, (May 29), 56.

34. Molta, D. (2003). The 10 deadly sins of wireless. Network Computing, (August 21), 73.

35. Molta, D. (2001). The road ahead for wireless. Networking computing. (July 9), 37.

36. Molta, D. (2003). Wireless hotspots heat up. Network Computing, (May 15), 35.

37. Munro, N. (2002). Internet without the wires. National Journal, 34(19), 1384.

38. Nelson, K. (2000). No strings attached. $B$ to $B, 85,13$.

39. Noble, C. (2003). New wireless options aplenty, but users wary. eWeek, (March 17), 18.

40. Peckham, R. (2003). WPA tightens wireless security. Communications News, 40(2), 6.

41. Preimesberger, C. (2003). Wireless trends: looking ahead at 2003. GameSpot Europe, (January 22).

42. Rash, W. (2000). The future is now for wireless e-commerce. InternetWeek, (February 14), 69.

43. Rose, F. (2003). Barry Diller has no vision for the future of the internet. Wired, (April), 191.

44. Rubin, R. (2003). Wanted: Wi-Fi lite. eWeek, (August 7).

45. Rysavy, P. (2003). Common goals, unique strengths. Network Computing, (May 15), 43.

46. Schlender, B. (2003). The vision thing again. Business 2.0, (December, 2003), 105.

47. $S \& M M$. (2003). How tech savvy are your salespeople? (September), 29.

48. Smith, S. (2003). Wi-Fi hotspots. eWeek, (August 8).

49. Terhune, C. \& Kahn, G. (2003). Coke lures Japanese customers with cellphone come-ons. The Wall Street Journal. 
50. Torode, C. \& Lingblom, M. (2003). Microsoft's mobile computing manifesto. InformationWeek, (March 20).

51. Tudor, J. (2003). Going online on the road. Online, 27(1), 23.

52. Tynan, D. (2003). New life for wireless CRM. Sales \& Marketing Management, (September), 28.

53. Van, J. (2003). Wireless opens doors for the deaf. Wired West. 5C.

54. Walker, L. (2003). No wires, no charge. Washington Post, (September 16).

55. XSVoice. (2001). Standardization and the wireless internet: falling into a familiar hole. Retrieved December 22, 2003 from http://www.xsvoice.com/docs/StandardizationArticle41.pdf 